\title{
Profile and compliance of recipients of injection depot medroxy progesterone acetate as a contraceptive method in the government tertiary care hospital in Mandya, South Karnataka, India
}

\author{
Shilpa M. N., Shwetha M.* \\ Department of Obstetrics and Gynecology, Mandya Institute of Medical Sciences, Mandya, Karnataka, India \\ Received: 18 December 2019 \\ Accepted: 30 December 2019 \\ *Correspondence: \\ Dr. Shwetha M., \\ E-mail: shwethabmc@gmail.com \\ Copyright: () the author(s), publisher and licensee Medip Academy. This is an open-access article distributed under \\ the terms of the Creative Commons Attribution Non-Commercial License, which permits unrestricted non-commercial \\ use, distribution, and reproduction in any medium, provided the original work is properly cited.
}

\begin{abstract}
Background: The advanced contraceptive devices available nowadays have minimal side effects and utmost efficacy. The use of safe and effective contraception is the need of the hour in India. Inj. Depot medroxy progesterone (DMPA) has been found to provide effective, long acting and reversible contraception in lactating mother and post-abortal patients. Objective of this study was to describe the profile of women utilizing inj. DMPA as a contraceptive, to determine its compliance and to assess the factors affecting discontinuation of inj. DMPA (Anthara) at the government tertiary care institute in Mandya.

Methods: The present study was a record-based study of 18 months (January 2018 to June 2019). The records of 266 women who utilized inj. DMPA as contraception in our institution was analysed.

Results: It was observed that out of 266 women $48.5 \%$ were from age group of 21-25 years and $64.3 \%$ were primipara. Most of the women who initiated inj. DMPA (Anthara) were in the lactational period (56.0\%). Most common side effect was irregular bleeding (54.8\%). Discontinuation rate was $55.6 \%$ after first injection and $16.9 \%$ after second injection and gradually reduced with subsequent injections. The most common reason for discontinuation was irregular spotting per vagina $(53.9 \%)$.

Conclusions: Inj. DMPA is a safe, effective, long acting contraceptive taken once in three months. Many women in early reproductive age and lactational period are using inj. DMPA (Anthara) for contraception because of its convenience of dosing and is easily made available at government health care centres free of cost and has no effect on lactation. Discontinuation rate can be reduced by proper counselling.
\end{abstract}

Keywords: Anthara, Compliance, Contraception, Depot medroxy progesterone, Profile

\section{INTRODUCTION}

India was the first country in the world to launch a Family Planning Programme, as early as 1952, with the main aim of controlling its population. Hence over the years India's National Family Planning Programme too has evolved with a shift in focus from merely population control to more critical issues of saving the lives and improving the health of mothers and children through use of reversible spacing methods leading to reduction in unwanted, closely spaced and mistimed pregnancies and thus avoiding pregnancies with higher risks and chances of unsafe abortions. Concerted efforts by the government have resulted in the decline of unmet need for family planning from $25.4 \%$ (DLHS-I) to $21.3 \%$ (DLHS-III) but approximately 4.2 crore couples still have an unmet need for contraception (1.6 crore for spacing and 2.6 crore for limiting)..$^{1,2}$

The recent data shows that unmet need for family planning among currently married women ranges from a low of 3 percent among women age 45-49 to a high of 22 
percent among women aged 15-24 years. ${ }^{3}$ A woman's reproductive right - including the right to decide the number, timing and spacing of her children - is absolutely fundamental to women empowerment and equality. ${ }^{4}$

The choice of contraceptives available to the women are many and also the efficacy of individual contraceptive device differs. The advanced contraceptive devices available nowadays have minimal side effects and utmost efficacy. The use of safe and effective contraception is the need of the hour in India. Individual preferences and socio-economic conditions of the people play a major role in acceptance of a contraceptive method. In the Indian scenario, much of the women have no role in making of reproductive decisions. The percentage of unwanted births increases with the mother's age, ranging from 1 percent of births to women less than 20 years of age to 33 percent of births to women aged $45-49$ years. $^{3}$

In this context, contraceptive counselling should be an integrated part of any abortion care and postpartum care to help women avoid another unplanned or unwanted pregnancy. Amongst popular methods offered like barrier contraception, Pills, IUCD and sterilization, injection Depot medroxy progesterone (DMPA) has been found to provide effective, long acting and reversible contraception in lactating mother and post-abortal patients. Added advantage is that it is to be given by intramuscular route and hence not much training is needed for the person administering the injection. ${ }^{5-9}$

The major problem with contraceptive pills and few other methods is the need for regular use. So, use of long acting contraception makes people free from daily usage of contraceptive pills or any other method. Even with long acting contraception, the acceptance of intra-uterine devices and injectable forms differs. Poor compliance from the contraceptive users also compels the health care professionals to advice for long acting contraceptive methods like Inj, DMPA, which has been part of the contraceptive programs of many countries for more than 20 years. ${ }^{10,11}$

And also, women are highly motivated and receptive to accept family planning (FP) methods during the postpartum period. ${ }^{12}$ Hence this study was undertaken to study the acceptance of inj DMPA among women seeking contraception from a tertiary health care institute.

\section{Objectives}

- To describe the profile of women utilizing Inj. DMPA as a contraceptive at government tertiary care institute in Mandya.

- To determine the compliance of Inj. DMPA utilization among these women.

- To assess the factors affecting discontinuation of DMPA utilization.

\section{METHODS}

A record based study was conducted over a period of 18 months (Jan 2018 to Jun 2019) among the women who utilized Inj DMPA contraception at tertiary care government hospital, Mandya.

Those who has chosen inj. Depot Medroxy Progesterone Acetate (DMPA) in the age group of 18 to 40 years as contraceptive recorded in the registers were included in this study. Women had received injection DMPA $150 \mathrm{mg}$ IM intramuscularly during the first week of menses, immediate post abortal or at 6 weeks of post-partum period. The ethics committee approval was taken prior to start of the study.

A total of 266 women were included in the study and their follow-up visits were noted subsequently from the records. The subjects received DMPA injections every 3 months in the study period. The available information like age, parity, timing of administration, information provider regarding DMPA injection that were entered during initiation of inj. DMPA and details regarding discontinuation of inj. DMPA that was collected and recorded in the register were entered into the proforma. The collected data was entered in Microsoft excel and analysed.

\section{Inclusion criteria}

- Women in the age group of 18 to 40 years who had taken inj. DMPA for contraception.

\section{Exclusion criteria}

- Hypertension, diabetes, liver disorder, vaginal bleeding of unknown etiology.

\section{RESULTS}

The mean age of the participants was $25.18 \pm 4.248$ years, the minimum age being 19 years and the maximum being 40 years.

Table 1: Age distribution of study subjects.

\begin{tabular}{|llll|}
\hline \multicolumn{1}{|c|}{ Characteristics } & Frequency & Percent \\
\hline \multirow{4}{*}{$\begin{array}{l}\text { Age } \\
\text { group }\end{array}$} & $\leq 20$ & 35 & 13.2 \\
\cline { 2 - 4 } & $21-25$ & 129 & 48.5 \\
\cline { 2 - 4 } & $26-30$ & 75 & 28.2 \\
\cline { 2 - 4 } & $31-35$ & 21 & 7.9 \\
\cline { 2 - 4 } & $\geq 36$ & 6 & 2.3 \\
\cline { 2 - 4 } & Total & $\mathbf{2 6 6}$ & $\mathbf{1 0 0 . 0}$ \\
\hline
\end{tabular}

The Table 1 shows the age distribution of the subjects taking DMPA. Majority of them were in the age group of 21 to 25 years $(48.5 \%)$ followed by $26-30$ years $(28.2 \%)$, $\leq 20$ years $(13.2 \%), 31-35$ years $(7.9 \%)$ and $\geq 36$ years $(2.3 \%)$. 
Nearly $2 / 3^{\text {rd }}(64.3 \%)$ of the participants were of the parity 1 status and the rest being para 2, 3, 4 (multipara - 33\%) and nullipara $(0.8 \%)$, as shown in Table 2.

Table 2: Distribution of subjects by their parity status.

\begin{tabular}{|lllllll|}
\hline Age group in years & Nullipara & $\mathbf{1}$ & $\mathbf{2}$ & $\mathbf{3}$ & $\mathbf{4}$ & Total \\
\hline$\leq 20$ & 1 & 30 & 4 & 0 & 0 & 35 \\
\hline $21-25$ & 1 & 88 & 40 & 0 & 0 & 129 \\
\hline $26-30$ & 0 & 42 & 29 & 3 & 1 & 75 \\
\hline $31-35$ & 0 & 11 & 9 & 1 & 0 & 21 \\
\hline$\geq 36$ & 0 & 0 & 5 & 1 & 0 & 6 \\
\hline Total & $\mathbf{2}$ & $\mathbf{1 7 1}$ & $\mathbf{8 7}$ & $\mathbf{5}$ & $\mathbf{1}$ & $\mathbf{2 6 6}$ \\
\hline Percent & 0.8 & 64.3 & 32.7 & 1.9 & 0.4 & 100 \\
\hline
\end{tabular}

Most of the women (56\%), who had taken Inj. DMPA were in the lactational period, the remaining in the interval period $(25.2 \%)$ and post abortal period $(18.4 \%)$ as depicted in Table 3.

Table 3: Distribution of subjects with DMPA intake in their lactation period, post abortal and interval period.

\begin{tabular}{|lll|}
\hline $\begin{array}{l}\text { Timing of } \\
\text { administration }\end{array}$ & $\begin{array}{l}\text { Frequency } \\
(\mathbf{n = 2 6 6})\end{array}$ & $\begin{array}{l}\text { Percentage } \\
(\mathbf{\%})\end{array}$ \\
\hline Lactational period & 150 & 56 \\
\hline Post abortal & 49 & 18.4 \\
\hline Interval & 67 & 25.2 \\
\hline Total & $\mathbf{2 6 6}$ & $\mathbf{1 0 0}$ \\
\hline
\end{tabular}

Most of the women were made aware about this method of contraception by health care providers, which constituted doctors (54.8\%), ASHA/ANM workers $(32.3 \%)$ as depicted in Table 4 . Table 5 indicates the number of patients taking the subsequent DMPA injections in the follow up period. The total number had reduced to 118 for the $2^{\text {nd }}$ injection, 98 for the 3 rd injection and 90 for the $4^{\text {th }}$ injection.

Table 4: Provider of awareness of Inj. DMPA as a method of contraception.

\begin{tabular}{|lll|}
\hline Provider & $\begin{array}{l}\text { Number of } \\
\text { women }(\mathbf{n}=\mathbf{2 6 6})\end{array}$ & $\begin{array}{l}\text { Percentage } \\
(\mathbf{\%})\end{array}$ \\
\hline Doctor & 146 & 54.8 \\
\hline ASHA/ANM & 86 & 32.3 \\
\hline Mass media & 8 & 3 \\
\hline Acquaintance & 26 & 9.7 \\
\hline
\end{tabular}

Table 5: DMPA injections receival status at subsequent follow up.

\begin{tabular}{|lllll|}
\hline Characteristics & $1^{\text {stinj }}$ DMPA & $2^{\text {ndinj DMPA }}$ & $3^{\text {rd }}$ Inj DMPA & $4^{\text {th }}$ Inj DMPA \\
\hline Follow up- Subjects taking DMPA & 266 & 118 & 98 & 90 \\
\hline
\end{tabular}

Table 6: Side effects of inj. DMPA reported by the subjects.

\begin{tabular}{|lll|}
\hline $\begin{array}{l}\text { Side effects of DMPA } \\
\text { Injection }\end{array}$ & $\begin{array}{l}\text { Number } \\
(\mathbf{N}=\mathbf{2 6 6})\end{array}$ & $\begin{array}{l}\text { Yes } \\
\text { (Percent) }\end{array}$ \\
\hline Irregular bleeding & 146 & 54.8 \\
\hline Amenorrhoea & 92 & 36.09 \\
\hline Scanty periods & 15 & 5.63 \\
\hline Mood changes & 5 & 1.87 \\
\hline Weight gain & 8 & 3.0 \\
\hline
\end{tabular}

Nearly half of the subjects $(54.8 \%)$ reported irregular bleeding as the most common side effect, followed by amenorrhoea $(36.09 \%)$, scanty periods $(5.63 \%)$, weight gain $(3.0 \%)$ and the rest with mood changes $(1.87 \%)$ as depicted in Table 6.
Table 7: Reasons for discontinuation among subjects taking DMPA.

\begin{tabular}{|lll|}
\hline $\begin{array}{l}\text { Reasons for } \\
\text { discontinuation }\end{array}$ & $\begin{array}{l}\text { Number } \\
(\mathbf{N}=176)\end{array}$ & $\begin{array}{l}\text { Yes } \\
\text { (Percent) }\end{array}$ \\
\hline Irregular spotting & 95 & 53.97 \\
\hline Amenorrhoea & 26 & 14.77 \\
\hline Planning pregnancy & 21 & 11.93 \\
\hline Change of contraception & 34 & 19.3 \\
\hline
\end{tabular}

The Table 7 shows the reason for discontinuation of inj. DMPA. The most common reason being irregular spotting per vagina contributing to $53.9 \%$ of discontinuation, followed by amenorrhoea $14.7 \%$, wanted to change contraceptive method $19.3 \%$ and planning pregnancy $11.93 \%$. 


\section{DISCUSSION}

In our study, the mean age of the participants was $25.18 \pm 4.248$ years, the minimum age being 19 years and the maximum being 40 years.

Majority of them were in the age group of 21 to 25 years $(48.5 \%)$ followed by $26-30$ years $(28.2 \%), \leq 20$ years (13.2\%), 31-35 years $(7.9 \%)$ and $\geq 36$ years $(2.3 \%)$. Similar findings where in the highest uptake was among women $\geq 25$ years of age $(78 \%)$ was seen in a multicentric study done by Benson J et al. ${ }^{13}$

The majority $2 / 3^{\text {rd }}(64.3 \%)$ of uptake of inj DMPA in our study were primipara, only $0.8 \%$ nullipara and the rest being multipara. In a study done by Patel $\mathrm{A}$ et al in Ahmedabad, $84 \%$ patients were multi para and $10 \%$ were primipara. ${ }^{8}$ This difference may be because of the different study setting and the socio-cultural factors. Most of the women $(56 \%)$, who had taken Inj. DMPA were in the lactational period, the remaining in interval period $(25.2 \%)$ and post abortal period (18.4\%). These findings of DMPA uptake in post-delivery are similar to the study done by Patel A et al (post-delivery-55\%), Rai L et al, $(51 \%)$ and Nautival R et al (42\%).

In our study, the total number of subjects who had taken Inj. DMPA had reduced to 118 for the $2^{\text {nd }}$ injection and to 98 for the $3^{\text {rd }}$ injection and 90 for the 4th injection. Four doses of injection DMPA during the study period was received by only $33.8 \%$ women Nearly half of the subjects $(54.8 \%)$ reported irregular bleeding as the most common side effect, followed by amenorrhoea $(36.09 \%)$, scanty periods $(5.2 \%)$, weight gain $(3.0 \%)$ and the rest with mood changes $(1.87 \%)$. These findings are similar to the findings in study done by Patel $\mathrm{A}$ et al and Rai L et al. ${ }^{6,8}$

The most common reason for discontinuation of inj DMPA in our study being irregular spotting per vagina contributing to $53.97 \%$ of discontinuation, followed by amenorrhoea $(14.7 \%)$, wanted to change contraceptive method $(19.3 \%)$ and planning pregnancy $(11.9 \%) .{ }^{6,15}$

\section{CONCLUSION}

Inj. DMPA is a safe, effective, long acting contraceptive taken once in three months. Many women in the early reproductive age are using inj. DMPA (Anthara) for contraception because of its convenience of dosing and is easily made available at government health care centres free of cost. The usage among breast feeding mothers was more as it did not affect lactation. Most of the women initiated inj DMPA as a contraceptive method from the advice given by health care providers. Major expected adverse effect of inj DMPA was menstrual disturbances and this itself was the main reason for its discontinuation. This could be reduced by proper counselling during initiation and reassurance during follow up
Funding: No funding sources

Conflict of interest: None declared

Ethical approval: The study was approved by the Institutional Ethics Committee

\section{REFERENCES}

1. Family Planning Division, Ministry of Health and Family Welfare. Reference manual For Injectable contraceptive (DMPA). New Delhi: Ministry of Health and Family Welfare, Government of India; 2016:96.

2. Nath J. Contraception in Postpartum Women of North India - A study of knowledge, concepts and practice. SF Obstet Women Health J. 2017;1:1.

3. International Institute for Population Sciences, Deonar. National Family Health Survey (NFHS-4). Mumbai: Ministry of Health and Family Welfare, Government of India; 2017:634.

4. Nath J, Islam F. A study on the knowledge, attitude and practice about contraception in postpartum women of North India. IJSR. 2015;4(12):465-8.

5. Rani S. A study on injectable DMPA (Depomedroxy progesterone acetale) $150 \mathrm{mg}$ use as short-term contraception in immediate postpartum women. IJMHR. 2017;3(9):17-22.

6. Rai L, Prabakar P, Nair S. Injectable Depot Medroxy progesterone- A safe and effective contraception for an Indian setting health and population- perspectives and issues. 2007;30(1):12-23.

7. Kashyap C, Mohanty IR, Thamke P, Deshmukh YA. Acceptance of contraceptive methods among postpartum women in a tertiary care centre. The $\mathbf{J}$ Obstet Gynecol India. 2017;67(2):91-7.

8. Patel A, Thakkar J, Patel MS, Khatri SA. A study of use of DMPA (injectable contraceptive) in postpartum and postabortal patients. Int J Scient Res. 2019;8(11):34-6.

9. Oranu. Review of contraception with depot medroxyprogesterone acetate at the University of Port Harcourt Teaching Hospital, Port Harcourt, Southern Nigeria. BJMMR. 2016;15(10):1-6.

10. Rabe T, Runnebaum B. eds. Fertility Control-Update and Trends. Springer - Verlag Berlin; 1999:121-149.

11. Mishra S, Gupta R. Acceptability and compliance of DMPA among rural women in Sitapur UP. Int J Clin Obstet Gynaecol. 2019;3(2):8-10.

12. Upmanyu P, Kanhere A. Acceptance of methods of family planning in patients undergoing repeat cesarean section. Int $\mathbf{J}$ Reprod Contracept Obstet Gynecol. 2016;5:976-9.

13. Benson J, Andersen K, Healy J, Brahmi D. What factors contribute to postabortion contraceptive uptake by young women? A program evaluation in 10 countries in Asia and sub-Saharan Africa. Glob Health Sci Pract. 2017;5(4):644-57.

14. Nautiyal R, Bijalwan R, Maithili B, Sinha LN. Feasibility of injectable Depot medroxyprogesterone acetate in a semi urban camp setting. Int $\mathbf{J}$ Reprod Contracept Obstet Gynecol. 2016;5(4):1056-60. 
15. Sirisha PSNRS. Efficacy of Depot Medroxy progesterone acetate as a contraceptive. Int J Med Res Pharma Sci. 2017;4(12):22-3.
Cite this article as: Shilpa MN, Shwetha M. Profile and compliance of recipients of injection depot medroxy progesterone acetate as a contraceptive method in the government tertiary care hospital in Mandya, South Karnataka, India. Int J Reprod Contracept Obstet Gynecol 2020;9:507-11. 